\title{
Serinicoccus marinus gen. nov., sp. nov., a novel actinomycete with L-ornithine and L-serine in the peptidoglycan
}

\author{
Correspondence \\ Jongsik Chun \\ jchun@snu.ac.kr
}

\author{
Hana Yi, ${ }^{1}$ Peter Schumann, ${ }^{2}$ Kyounghee Sohn ${ }^{1}$ and Jongsik Chun ${ }^{1}$ \\ ${ }^{1}$ School of Biological Sciences, Seoul National University, 56-1 Shillim-dong, Kwanak-gu, \\ Seoul 151-742, Republic of Korea \\ ${ }^{2} \mathrm{DSMZ}$ - German Collection of Microorganisms and Cell Cultures, Mascheroder Weg 1b, \\ D-38124 Braunschweig, Germany
}

\begin{abstract}
A Gram-positive bacterial strain containing L-ornithine as the diagnostic diamino acid was isolated from a sea-water-sample from the East Sea, Korea. A phylogenetic analysis based on $16 \mathrm{~S}$ rRNA gene sequences showed that strain $\mathrm{JC} 1078^{\top}$ represents a phyletic line within the suborder Micrococcineae of the order Actinomycetales, adjacent to the genus Ornithinimicrobium. The highest sequence similarity values to the isolate were observed against Ornithinimicrobium humiphilum (94.3\%) and Kytococcus sedentarius (94.1\%). The strain was strictly aerobic and moderately halophilic with optimal growth at 2-3\% (w/v) $\mathrm{NaCl}$. Cells were non-motile, non-sporulating and coccoid-shaped. The cell wall contains L-ornithine, glutamic acid, alanine, glycine and serine. The major menaquinone was $\mathrm{MK}-8\left(\mathrm{H}_{4}\right)$. The predominant cellular fatty acids were of the iso- and anteiso-methyl-branched types. The polar lipids were phosphatidylglycerol, diphosphatidylglycerol, phosphatidylinositol and an unknown glycolipid. The acyl type of the glycan chain of peptidoglycan is acetyl. The DNA G+C content was 72 mol\%. The combination of physiological, biochemical and chemotaxonomical data clearly separated the marine isolate from other members of the suborder Micrococcineae. On the basis of polyphasic evidence, it is proposed to classify strain $\mathrm{JC} 1078^{\top}$ in a novel genus and species, for which the name Serinicoccus marinus gen. nov., sp. nov. is proposed. The type strain is $\mathrm{JC}^{1078^{\top}}$ $\left(=\right.$ IMSNU $14026^{\top}=$ KCTC $9980^{\top}=$ DSM $\left.15273^{\top}\right)$.
\end{abstract}

Actinomycetes containing ornithine as the diagnostic diamino acid in their peptidoglycans are phylogenetically assigned to the families Cellulomonadaceae (Cellulomonas, Rarobacter) and Microbacteriaceae (Microbacterium, Curtobacterium) within the suborder Micrococcineae (Stackebrandt et al., 1997). In addition, two genera, namely Ornithinicoccus and Ornithinimicrobium, have been proposed to harbour organisms containing ornithine in the peptidoglycan (Groth et al., 1999, 2001). The differentiation of these two genera was based on the peptidoglycan structure, polar lipid pattern, fatty acid profile and morphology as well as 16S rRNA gene analysis (Groth et al., 2001). In this study, we report the polyphasic characterization of a marine isolate containing ornithine in the peptidoglycan and propose to classify the organism in a novel genus and species, for which the name Serinicoccus marinus gen. nov., sp. nov. is proposed.

Published online ahead of print on 5 March 2004 as DOI 10.1099/ ijs.0.3036-0.

The GenBank accession number for $16 \mathrm{~S}$ rRNA gene sequence of strain $\mathrm{JC} 1078^{\top}$ is $\mathrm{AY} 382898$.
Strain $\mathrm{JC} 0178^{\mathrm{T}}$ was isolated from a surface sea-watersample collected from the East Sea using the standard dilution plating technique. Isolation was achieved using Marine agar 2216 (MA; Difco) and incubation at $30^{\circ} \mathrm{C}$. The isolate was routinely cultured on MA and maintained as a glycerol suspension $(20 \%, \mathrm{w} / \mathrm{v})$ at $-80^{\circ} \mathrm{C}$.

The 16S rRNA gene was enzymically amplified from a single colony. Primers, PCR conditions and sequencing were described elsewhere (Chun \& Goodfellow, 1995). The sequence of strain $\mathrm{JC} 1078^{\mathrm{T}}$ was manually aligned with representative sequences of actinomycetes obtained from the GenBank database. Phylogenetic trees were inferred by using the Fitch-Margoliash (Fitch \& Margoliash, 1967), maximum-likelihood (Felsenstein, 1981), maximumparsimony (Fitch, 1972) and neighbour-joining (Saitou \& Nei, 1987) methods. Evolutionary distance matrices for the neighbour-joining and Fitch-Margoliash methods were generated according to the model of Jukes \& Cantor (1969). The resultant neighbour-joining tree topology was evaluated by bootstrap analyses (Felsenstein, 1985) based on 1000 resamplings. The alignment and phylogenetic analyses were carried out using the PHYDIT program 
(available at http://plaza.snu.ac.kr/ jchun/phydit/) and PAUP 4.0 (Swofford, 1998) as described (Chun et al., 2000).

A nearly complete 16S rRNA gene sequence of strain $\mathrm{JC} 1078^{\mathrm{T}}$ was obtained (1420 bp). Preliminary sequence comparison against the $16 \mathrm{~S}$ rRNA gene sequences deposited in the GenBank database indicated that our isolate belonged to the suborder Micrococcineae in the order Actinomycetales. On the basis of $16 \mathrm{~S}$ rRNA gene similarity, the closest cultured relatives were Ornithinimicrobium humiphilum DSM $12362^{\mathrm{T}}(94 \cdot 3 \%)$, Kytococcus sedentarius DSM $20547^{\mathrm{T}}$ (94.1\%), Dermacoccus nishinomiyaensis DSM $20448^{\mathrm{T}}$ (93.9\%), Arthrobacter cumminsii DSM $10493^{\mathrm{T}}$ (93.7\%), Demetria terragena DSM $11295^{\mathrm{T}}(93.7 \%)$, Arthrobacter albus CF- $43^{\mathrm{T}}(93.5 \%)$ and Janibacter limosus DSM $11140^{\mathrm{T}}$ $(93 \cdot 1 \%)$. This relationship between our isolate and other members of the suborder Micrococcineae was also evident in the phylogenetic trees (Fig. 1). Strain $\mathrm{JC}^{1078^{\mathrm{T}}}$ and Ornithinimicrobium humiphilum DSM $12362^{\mathrm{T}}$ formed a monophyletic clade with a relatively low bootstrap value (49\%) which was supported by all tree-making methods employed in this study. The positions of the other taxa that showed more than $93 \% 16 \mathrm{~S}$ rRNA gene sequence similarities to our marine isolate varied depending on the inferring algorithm.

Cellular morphology and motility were examined after growth on MA at $30^{\circ} \mathrm{C}$ for 3 days by scanning electron and phase-contrast microscopy, respectively. The strain was checked for the formation of mycelium and spores by growing on several culture media, namely MA, ISP medium \#3 (Difco), ISP medium \#4 (Difco), PYGV (Staley, 1968) supplemented by artificial sea water (ASW; Lyman \& Fleming, 1940), nutrient agar (Difco) supplemented by ASW and basal medium (BM; Baumann et al., 1972).

Growth under anaerobic conditions was determined in an anaerobic chamber $\left(10 \% \mathrm{CO}_{2}, 10 \% \mathrm{H}_{2}, 80 \% \mathrm{~N}_{2}\right.$; Sheldon Manufacturing). The growth range for temperature (between 5 and $50{ }^{\circ} \mathrm{C}$ with intervals of $5^{\circ} \mathrm{C}$ ), $\mathrm{pH}$ (between
$\mathrm{pH} 4$ and 12 with intervals of 1) and $\mathrm{NaCl}$ concentration [between 0 and $15 \%(\mathrm{w} / \mathrm{v})$ with intervals of $1 \%$ ] was determined using synthetic ZoBell medium (Zobell, 1941); growth was checked after up to 4 weeks.

Standard physiological and biochemical tests were performed as described previously (Smibert \& Krieg, 1994). Acid-fastness was determined by Ziehl-Neelsen staining. Hydrolysis of alginic acid, casein, cellulose, chitin, starch and Tween 80 was tested using MA as the basal medium. DNase test agar (Difco) supplemented with $2 \cdot 5 \%(\mathrm{w} / \mathrm{v})$ $\mathrm{NaCl}$ was used for DNase assay. Decomposition of adenine, hypoxanthine, L-tyrosine and xanthine was tested using MA according to Gordon et al. (1974). Production of $\mathrm{H}_{2} \mathrm{~S}$ was detected in triple-sugar iron agar (TSI) supplemented with $2.5 \%(\mathrm{w} / \mathrm{v}) \mathrm{NaCl}$. Arginine dihydrolase, $\beta$-galactosidase, nitrate reduction, urease, acid production from glucose and indole production tests were performed using an API 20NE kit (bioMérieux), and other enzymic activities were determined using an API ZYM kit (bioMérieux). Strips were inoculated with a heavy bacterial suspension in half-strength ASW and AUX medium supplemented with $2 \cdot 5 \%(\mathrm{w} / \mathrm{v}) \mathrm{NaCl}$. $\beta$-Galactosidase activity was additionally determined by streaking cultures onto MA agar plates amended with $0 \cdot 1 \mathrm{mM}$ IPTG and $20 \mu \mathrm{g}$ X-Gal $\mathrm{ml}^{-1}$ (Gosink et al., 1998). Carbon source utilization was tested in 96-well tissue culture microplates as described by Gosink et al. (1998) using BM supplemented with $1 \%$ (v/v) of vitamin solution (Staley, 1968) as basal medium.

The results of biochemical and physiological tests are presented in the genus and species description.

Extraction of fatty acid methyl esters and their gas chromatographic separation were performed by using the Microbial Identification System according to the instructions in the operating manual (MIDI, 1999). The peptidoglycan structure was elucidated by analysis of purified cell-wall hydrolysates according to Schleifer (1985). The amino acids and peptides were analysed by two-dimensional

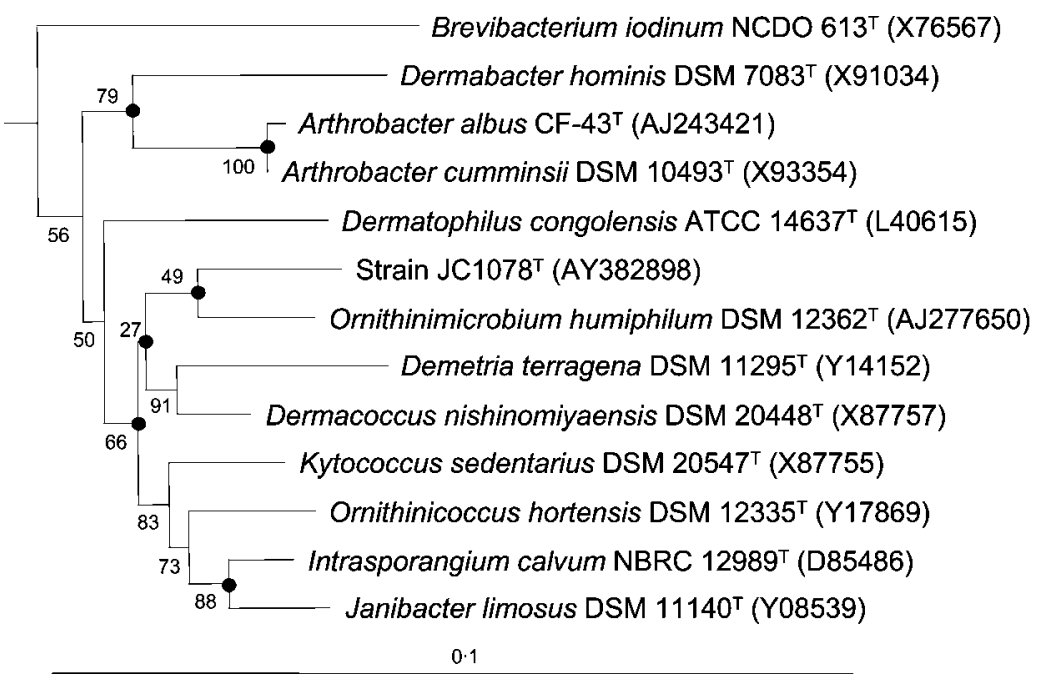

Fig. 1. Neighbour-joining tree based on nearly complete $16 \mathrm{~S}$ rRNA gene sequences showing relationships between strain $\mathrm{JC}_{1078}{ }^{\mathrm{T}}$ and members of the suborder Micrococcineae. The percentage numbers at the nodes are the levels of bootstrap support based on neighbour-joining analyses of 1000 resampled datasets, and solid circles indicate that the corresponding nodes (groupings) are also recovered in FitchMargoliash, maximum-likelihood and maximumparsimony trees. Helicobacter pylori ATCC $43504^{\top}$ (M88157) was used as an outgroup. Scale bar, 0.1 nucleotide substitutions per position. 
ascending TLC on cellulose plates using the solvent systems of Schleifer \& Kandler (1972). The molar ratios of amino acids were determined by GC and GC/MS of $\mathrm{N}$ heptafluorobutyryl amino acid isobutyl esters (MacKenzie, 1987; Groth et al., 1996). The amino terminal amino acid of the interpeptide bridge was determined by dinitrophenylation as described by Schleifer (1985). The glycolate content of bacterial cell walls was determined by the colorimetric method of Uchida \& Aida (1984). Menaquinones were extracted according to Collins et al. (1977) and were analysed by HPLC (Groth et al., 1996).

DNA for determination of the $\mathrm{G}+\mathrm{C}$ value was isolated using a French pressure cell (ThermoSpectronic) and purified on hydroxyapatite as described by Cashion et al. (1977). The G $+\mathrm{C}$ content was determined by reverse-phase HPLC of nucleosides according to Mesbah et al. (1989).

The peptidoglycan of strain $\mathrm{JC} 1078^{\mathrm{T}}$ contained ornithine, alanine, glycine, serine and glutamic acid in an approximate molar ratio of $1: 2: 2: 1: 3$. Labelling by 1 -fluoro-2,4dinitrobenzene revealed that serine represents the amino terminus of the interpeptide bridge. Dinitrophenylated glutamic acid could not be detected. The peptide L-AlaD-Glu typical of peptidoglycans of the A-type of crosslinkage was found in the partial hydrolysate $(4 \mathrm{M} \mathrm{HCl}$, $\left.100^{\circ} \mathrm{C}, 45 \mathrm{~min}\right)$. Because the results of the peptidoglycan analysis are inconsistent with all hitherto published structures of peptidoglycans containing ornithine and serine (http://www.dsmz.de/species/murein.htm) and because of the phylogenetic proximity to Ornithinicoccus hortensis and Ornithinimicrobium humiphilum, it is likely that strain $\mathrm{JC} 1078^{\mathrm{T}}$ represents a novel variation of peptidoglycan type A4 $\beta$. However, a detailed peptidoglycan structure can not be concluded from the available data. The acyl type of the glycan chain of peptidoglycan is acetyl. The major menaquinone of strain $\mathrm{JC} 1078^{\mathrm{T}}$ was MK- $8\left(\mathrm{H}_{4}\right)$. The polar lipid pattern consisted of phosphatidylglycerol, diphosphatidylglycerol, phosphatidylinositol and an unidentified glycolipid. The cellular fatty acids were i-14:0 (1.30\%), i-15: 1 (1.88\%), i-15:0 (41.65\%), ai-15:0 (8.18\%), $15: 0(0 \cdot 89 \%), \mathrm{i}-16: 0(0 \cdot 79 \%), \mathrm{i}-16: 0(12 \cdot 83 \%), 16: 0$ $(1 \cdot 79 \%), \mathrm{i}-17: 1 \omega 9 \mathrm{c}(12 \cdot 21 \%), \mathrm{i}-17: 0(9 \cdot 24 \%)$, ai-17:0 $(6.96 \%), 17: 1 \omega 8 \mathrm{c}(1.00 \%)$ and $17: 0(1.28 \%)$. The DNA base composition of strain $\mathrm{JC} 1078^{\mathrm{T}}$ was $72 \mathrm{~mol} \% \mathrm{G}+\mathrm{C}$.

Strain $\mathrm{JC} 1078^{\mathrm{T}}$ corresponds to its phylogenetic neighbour Ornithinimicrobium humiphilum and to Ornithinicoccus hortensis in displaying an A-type peptidoglycan based on ornithine, in the DNA base composition of approximately $70 \mathrm{~mol} \% \mathrm{G}+\mathrm{C}$ and in the major menaquinone $\mathrm{MK}-8\left(\mathrm{H}_{4}\right)$. However, strain $\mathrm{JC} 1078^{\mathrm{T}}$ can be differentiated from both genera by the occurrence of serine in the peptidoglycan and by its polar lipid pattern, fatty acid profile and physiological characteristics as shown in Table 1. All other phylogenetically related genera of the suborder Micrococcineae can be differentiated easily from strain $\mathrm{JC} 1078^{\mathrm{T}}$ by phenotypic characteristics such as the peptidoglycan structure. Based on the differentiation from all validly described genera of the suborder Micrococcineae by phylogenetic analysis, chemotaxonomic investigations and physiological studies, it is proposed to classify the new isolate in a novel genus and species, Serinicoccus marinus gen. nov., sp. nov., with the type strain $\mathrm{JC} 1078^{\mathrm{T}}$.

\section{Description of Serinicoccus gen. nov.}

Serinicoccus (Ser.in'i.coc.cus. N.L. n. serinum serine; N.L. masc. n. coccus from Gr. masc. n. kokkos a grain, seed; N.L. masc. n. Serinicoccus a coccus with serine in the cell wall).

Gram-positive, strictly aerobic, moderately halophilic bacteria. Oxidase-negative, catalase-positive, not acid-fast. No formation of spores. Cells are non-motile cocci. The peptidoglycan type is of the A type of cross-linkage and contains ornithine, alanine, glycine, serine and glutamic acid in an approximate molar ratio of $1: 2: 2: 1: 3$. The acyl type of the glycan chain of peptidoglycan is acetyl. The major menaquinone is $\mathrm{MK}-8\left(\mathrm{H}_{4}\right)$. The major cellular fatty acids are of the iso- and anteiso-methyl-branched type. The polar lipids are phosphatidylglycerol, diphosphatidylglycerol, phosphatidylinositol and one unknown glycolipid. The DNA G + C content is $72 \%$. Phylogenetically, this genus is affiliated to the suborder Micrococcineae. The type species is Serinicoccus marinus.

\section{Description of Serinicoccus marinus sp. nov.}

Serinicoccus marinus (ma.ri'nus. L. masc. adj. marinus of or belonging to the sea, marine).

In addition to the characteristics that define the genus, it has the characteristics described below. Growth occurs at $\mathrm{NaCl}$ concentrations of $0-14 \%(\mathrm{w} / \mathrm{v})$, the optimum being $2-3 \%$. The $\mathrm{pH}$ range for growth is between $\mathrm{pH} 6$ and 11 , the optimum being $\mathrm{pH}$ 8. The temperature range for growth is $10-35^{\circ} \mathrm{C}$, with the optimum being $35^{\circ} \mathrm{C}$. Extended incubation (up to 20 days) is required at $5^{\circ} \mathrm{C}$. Cells are cocci with diameters of $0 \cdot 5-0 \cdot 9 \mu \mathrm{m}$. Colonies on MA are yellow, circular, convex, entire, glistening, opaque and butyraceous. Colonies are approximately $1 \mathrm{~mm}$ in diameter after 3 days (on MA at $30^{\circ} \mathrm{C}$ ) and reach the maximum diameter of $3 \sim 4 \mathrm{~mm}$ after 5 days. Nitrate is reduced to nitrite. Does not show arginine dihydrolase activity. $\beta$-Galactosidase activity is weakly present. Does not produce $\mathrm{H}_{2} \mathrm{~S}$ on TSI agar, acid from glucose in API 20NE kit or indole from tryptophan. Casein, DNA, aesculin, gelatin, starch, Tween 80 and tyrosine are decomposed; adenine, alginate, cellulose, chitin, hypoxanthine, urea and xanthine are not. Tested by the API ZYM enzyme assay, strain $\mathrm{JC} 1078^{\mathrm{T}}$ is positive for esterase (C4), esterase lipase (C8), leucine arylamidase, valine arylamidase and $\alpha$-glucosidase; variable for trypsin and $\beta$-glucosidase; negative for alkaline phosphatase, lipase (C14), cystine arylamidase, $\alpha$-chymotrypsin, acid phosphatase, naphtholAS-BI-phosphohydrolase, $\alpha$-galactosidase, $\beta$-galactosidase, $\beta$-glucuronidase, $N$-acetyl- $\beta$-glucosaminidase, $\alpha$-mannosidase or $\alpha$-fucosidase. Utilizes acetate, D-cellobiose, D-fructose, 
Table 1. Major characteristics that differentiate strain $\mathrm{JC} 1078^{\top}$ from phylogenetically related ornithine-containing bacteria

Strains: 1, JC1078 $;$; , Ornithinimicrobium humiphilum DSM $12362^{\mathrm{T}}$; 3, Ornithinicoccus hortensis DSM $12335^{\mathrm{T}}$. Data are from this and earlier studies (Groth et al., 1999, 2001). Abbreviations: Orn, ornithine; Ala, alanine; Gly, glycine; Glu, glutamate; Ser, serine; Asp, aspartate; PG, phosphatidylglycerol; DPG, diphosphatidylglycerol; PI, phosphatidylinositol; PSer, phosphatidylserine; PLs, unknown phospholipids; GL(s), unknown glycolipid(s); I, iso-methyl-branched; A, anteiso-methyl-branched; S, straight chain saturated. Fatty acid type: fatty acids which show more than $5 \%$ of total composition are considered.

\begin{tabular}{|c|c|c|c|}
\hline Characteristic & 1 & 2 & 3 \\
\hline Cell morphology & Cocci & Cocci, irregular rods & Cocci \\
\hline Growth in the presence of $12 \% \mathrm{NaCl}$ & + & - & - \\
\hline Growth at $45^{\circ} \mathrm{C}$ & - & + & - \\
\hline Wall amino acids & Orn, Ala, Gly, Glu, Ser & Orn, Ala, Gly, Glu, Asp & Orn, Ala, Gly, Glu \\
\hline Polar lipid type & PG, DPG, PI, GL & PG, DPG, PI, PLs, GLs & PG, DPG, PI, PLs, PSer \\
\hline Fatty acid type & I, A & $\mathrm{I}, \mathrm{A}$ & I, A, S \\
\hline $\mathrm{G}+\mathrm{C}$ content $(\mathrm{mol} \%)$ & 72 & 70 & 72 \\
\hline Nitrate reduction & - & + & + \\
\hline $\mathrm{H}_{2} \mathrm{~S}$ production & - & + & + \\
\hline \multicolumn{4}{|l|}{ Decomposition of: } \\
\hline Aesculin & + & - & - \\
\hline Hypoxanthine & - & + & + \\
\hline Starch & + & + & - \\
\hline Tween 80 & + & - & + \\
\hline Tyrosine & + & - & - \\
\hline Xanthine & - & + & + \\
\hline \multicolumn{4}{|l|}{ API ZYM: } \\
\hline Alkaline phosphatase & - & + & + \\
\hline Lipase (C14) & - & - & $\mathrm{w}$ \\
\hline Cystine arylamidase & - & + & + \\
\hline$\alpha$-Chymotrypsin & - & $\mathrm{w}$ & + \\
\hline Acid phosphatase & - & + & $\mathrm{w}$ \\
\hline Naphthol-AS-BI-phosphohydrolase & - & + & + \\
\hline
\end{tabular}

D-galactose, D-glucose, D-mannitol, D-mannose, D-sorbitol, D-trehalose, glycerol and sucrose as a sole carbon source. Does not utilize acetamide, benzoate, citrate, D-ribose, ethanol, glycine, inulin, 2-propanol, lactose, L-arginine, L-ascorbate, L-lysine, L-rhamnose, $\mathrm{N}$-acetylglucosamine, polyethylene glycol, salicylate or tartrate. The major fatty acids are i-15:0, i-16:0, i-17: $1 \omega 9 c, \mathrm{i}-17: 0$, ai-15:0 and ai- $17: 0$. The DNA G $+\mathrm{C}$ content is $72 \mathrm{~mol} \%$.

The type strain, JC1078 ${ }^{\mathrm{T}} \quad\left(=\mathrm{IMSNU} \quad 14026^{\mathrm{T}}=\mathrm{KCTC}\right.$ $9980^{\mathrm{T}}=\mathrm{DSM} 15273^{\mathrm{T}}$ ), was isolated from a sea-water sample from the East Sea, Korea.

\section{Acknowledgements}

We are grateful to Dr J. P. Euzéby for the help with nomenclature. This work was supported by the $21 \mathrm{C}$ Frontier Microbial Genomics and Applications Center Program (grant MG02-0101-001-2-1-0) and the Strategic National R\&D Program through the Genetic Resources and Information Network (grant M1-0219-00-0018), MOST, Republic of Korea.

\section{References}

Baumann, L., Baumann, P., Mandel, M. \& Allen, R. D. (1972). Taxonomy of aerobic marine eubacteria. J Bacteriol 110, 402-429.
Cashion, P., Holder-Franklin, M. A., McCully, J. \& Franklin, M. (1977). A rapid method for base ratio determination of bacterial DNA. Anal Biochem 81, 461-466.

Chun, J. \& Goodfellow, M. (1995). A phylogenetic analysis of the genus Nocardia with $16 \mathrm{~S}$ rRNA gene sequences. Int J Syst Bacteriol 45, 240-245.

Chun, J., Bae, K. S., Moon, E. Y., Jung, S. O., Lee, H. K. \& Kim, S. J. (2000). Nocardiopsis kunsanensis sp. nov., a moderately halophilic actinomycete isolated from a saltern. Int J Syst Evol Microbiol 50, 1909-1913.

Collins, M. D., Pirouz, T., Goodfellow, M. \& Minnikin, D. E. (1977). Distribution of menaquinones in actinomycetes and corynebacteria. J Gen Microbiol 100, 221-230.

Felsenstein, J. (1981). Evolutionary trees from DNA sequences: a maximum likelihood approach. J Mol Evol 17, 368-376.

Felsenstein, J. (1985). Confidence limits on phylogenies: an approach using the bootstrap. Evolution 39, 783-791.

Fitch, W. M. (1972). Toward defining the course of evolution: minimum change for a specific tree topology. Syst Zool 20, 406-416.

Fitch, W. M. \& Margoliash, E. (1967). Construction of phylogenetic trees. Science 155, 279-284.

Gordon, R. E., Barnett, D. A., Handerhan, J. E. \& Pang, C. H.-N. (1974). Nocardia coeliaca, Nocardia autotrophica, and the nocardin strain. Int J Sys Bacteriol 24, 54-63.

Gosink, J. J., Woese, C. R. \& Staley, J. T. (1998). Polaribacter gen. nov., with three new species, $P$. irgensii sp. nov., $P$. franzmannii sp. 
nov. and $P$. filamentus sp. nov., gas vacuolate polar marine bacteria of the Cytophaga-Flavobacterium-Bacteroides group and reclassification of 'Flectobacillus glomeratus' as Polaribacter glomeratus comb. nov. Int J Syst Bacteriol 48, 223-235.

Groth, I., Schumann, P., Weiss, N., Martin, K. \& Rainey, F. A. (1996). Agrococcus jenensis gen. nov., sp. nov., a new genus of actinomycetes with diaminobutyric acid in the cell wall. Int J Syst Bacteriol 46, 234-239.

Groth, I., Schumann, P., Martin, K., Schuetze, B., Augsten, K., Kramer, I. \& Stackebrandt, E. (1999). Ornithinicoccus hortensis gen. nov., sp. nov., a soil actinomycete which contains L-ornithine. Int J Syst Bacteriol 49, 1717-1724.

Groth, I., Schumann, P., Weiss, N., Schuetze, B., Augsten, K. \& Stackebrandt, E. (2001). Ornithinimicrobium humiphilum gen. nov., sp. nov., a novel soil actinomycete with L-ornithine in the peptidoglycan. Int J Syst Evol Microbiol 51, 81-87.

Jukes, T. H. \& Cantor, C. R. (1969). Evolution of protein molecules. In Mammalian Protein Metabolism, pp. 21-132. Edited by H. N. Munro. New York: Academic Press.

Lyman, J. \& Fleming, R. H. (1940). Composition of sea water. J Mar Res 3, 134-146.

MacKenzie, S. L. (1987). Gas chromatographic analysis of amino acids as the $N$-heptafluorobutyryl isobutyl esters. J Assoc Off Anal Chem 70, 151-160.

Mesbah, M., Premachandran, U. \& Whitman, W. B. (1989). Precise measurement of the $\mathrm{G}+\mathrm{C}$ content of deoxyribonucleic acid by high-performance liquid chromatography. Int J Syst Bacteriol 39, 159-167.
MIDI (1999). Sherlock, Microbial Identification System, Operating Manual, version 3.0. Newark, DE: MIDI, Inc.

Saitou, N. \& Nei, M. (1987). The neighbor-joining method: a new method for reconstructing phylogenetic trees. Mol Biol Evol 4, 406-425.

Schleifer, K. H. (1985). Analysis of the chemical composition and primary structure of murein. Methods Microbiol 18, 123-156.

Schleifer, K. H. \& Kandler, O. (1972). Peptidoglycan types of bacterial cell walls and their taxonomic implications. Bacteriol Rev 36, 407-477.

Smibert, R. M. \& Krieg, N. R. (1994). Phenotypic characterization. In Methods for General and Molecular Bacteriology, pp. 607-654. Washington, DC: American Society for Microbiology.

Stackebrandt, E., Rainey, F. A. \& Ward-Rainey, N. L. (1997). Proposal for a new hierarchic classification system, Actinobacteria classis nov. Int J Syst Bacteriol 47, 479-491.

Staley, J. T. (1968). Prosthecomicrobium and Ancalomicrobium: new prosthecate freshwater bacteria. J Bacteriol 95, 1921-1942.

Swofford, D. L. (1998). Phylogenetic Analysis Using Parsimony (PAUP). Version 4. Sunderland, MA: Sinauer Associates.

Uchida, K. \& Aida, K. (1984). An improved method for the glycolate test for simple identification of the acyl type of bacterial cell walls. J Gen Appl Microbiol 30, 131-134.

Zobell, C. E. (1941). Studies on marine bacteria. I. The cultural requirements of heterotrophic aerobes. J Mar Res 4, 42-75. 